\title{
Global Nurse Migration Today
}

\author{
Barbara L. Brush
}

\begin{abstract}
Purpose: To examine emerging trends in global nurse migration and those effects on nurse workforce planning and development efforts in select donor and recipient countries.

Design and Methods: This integrative literature review is an analysis of current literature (journal articles, media, and press releases) and data from various sources (PUMS, NSSRN, CGFNS, Nurse \& Midwifery Council) to explicate new trends in nurse migration.

Findings: Rapid changes in nurse migration are significantly challenging nurse workforce management efforts in both donor and recipient nations.

Conclusions: As the market demand for nurses around the globe escalates, the changes and consequences associated with nurse migration are increasingly in need of policy solutions that indicate the needs and motivations of all stakeholders.
\end{abstract}

[Key words: nurse migration, migrant nurses, foreign nurses, nurse workforce]

Journal of Nursing ScholarShip, 2008; 40:1, 20-25. C2008 Sigma Theta Tau International.

$\mathrm{F}$ or over 6 decades, healthcare institutions in the United States (US), particularly hospitals in large urban communities among a few states, have recruited foreign nurses to fill staff-nurse vacancies during periods of shortage (Brush \& Berger, 2002). In more recent years, however, nurse migration has intensified in both scope and magnitude in the US and throughout the world. The "carousel" of nurses' international mobility (Kingma, 2006), once a oneway exchange among a few developed and developing countries, has become a more complicated and circuitous stream of global health workers flowing in new directions and patterns. Greater competition for nurse migrants among a lot of recruiting countries has created a market demand that is translated into big business (Brush, Sochalski, \& Berger, 2004), and with it, more change, more competition, and more consequences.

This paper is to indicate recent trends in global nurse migration, and shows changes in nurse migration and the effects on nurse workforce planning and development efforts in the US as well as in select donor and recipient countries. As will be shown, the shortage of nurses is affecting every nation; many countries both send and receive nurses; others are becoming increasingly reliant on foreign nurses or are experiencing nurse shortages of critical proportions. Evidence is increasing, moreover, that measures to resolve local and national nurse shortages are interfering with international nurse workforce goals, including those set forth by the World Health Organization (WHO), International Council of Nurses (ICN), and other international bodies. In many countries, demand for migrant nurses is exceeding the available supply and threatening the public's health. Representatives from other countries, mean- while, have gained from the lucrative nurse migration enterprise and continue to import nurses to satisfy their staffing needs.

\section{Changing U.S. Nurse Importation Patterns}

The US has long used foreign nurse recruitment as a strategy to fill staff vacancies, although the proportion of foreign to American nurses nationally has been low (Brush \& Berger, 2002). Preliminary findings of the Health Resources and Services Administration's (HRSA) 2004 National Sample Survey of Registered Nurses (NSSRN), for example, indicated the estimate that only $3.5 \%$ or 100,791 of all registered nurses (RNs) practicing in the US in 2003 received their basic nursing education in another country (HRSA, 2004). Most nurses emigrated from the Philippines $(50.2 \%)$, Canada $(20.2 \%)$, and the United Kingdom (UK; $8.4 \%)$, with nurses from Nigeria $(2.3 \%)$, Ireland $(1.5 \%)$, India $(1.3 \%)$, Hong Kong $(1.2 \%)$, Jamaica $(1.1 \%)$, Israel $(1.0 \%)$ and South Korea $(1.0 \%)$ ranking a distant fourth through tenth. Foreign-trained nurses entering the US were also geographically clustered, working primarily in urban communities in California (25.5\%), Florida (9.6\%), New

Barbara L. Brush, RN, PhD, FAAN, $X i$ and Rho, Associate Professor, The University of Michigan School of Nursing, Ann Arbor, MI. This work is supported by a grant from the National Library of Medicine. The author acknowledges the assistance of Dr. Catherine Davis at CGFNS for support in compiling data related to recent trends regarding foreign nurses taking the CGFNS exam. Correspondence to Dr. Brush, The University of Michigan School of Nursing, 400 North Ingalls, Room 3304, Ann Arbor, MI 48109. E-mail: brushb@umich.edu Accepted for publication October 12, 2007. 
York $(9.3 \%)$, Texas $(6.7 \%)$, and New Jersey $(6.1 \%$; HRSA, 2004).

In 2002, for example, New York State Education Department (NYSED, 2003) officials reported that $30 \%$ of New York City's (NYC) registered nurse (RN) pool was foreign educated compared to $12.4 \%$ of foreign-trained nurses across the state. Foreign nurses were 20 times more likely to work in NYC than in metropolitan areas in the upper part of the state and 12 times more likely to work in NYC than in the state's rural communities (Brewer, Feeley, \& Servoss, 2003).

Projected nurse shortages in California and Texas have led to increased recruitment of foreign trained nurses to meet nursing needs in these states as well (California Board of Registered Nursing, 2004; Reineck, Furino, Lucke, Martinez, \& Wood, 2005). In the past 2 years, California officials have increased international nurse recruitment considerably, while in Texas, foreign-nurse use increased $41.5 \%$ in its border communities alone, where the shortage of nurses is most pronounced (Center for California Health Workforce Studies, 2005; Sanchez \& Raimer, 2004; Texas Center for Nursing Workforce Studies, 2006).

Although foreign nurses remain geographically clustered, new trends show that many hospitals across the US are importing nurses to meet their staffing needs, some for the first time. A recent analysis of foreign-trained nurse trends, using U.S. Census Public Use Microdata Sample (PUMS) data, indicated that foreign-trained nurses represented $15.2 \%$ of new entrants to the U.S. RN labor force in 2000 (Polsky, Ross, Brush, \& Sochalski, 2007), a figure that has likely risen in the past 7 years. Rural community hospitals, where nursing deficits are reaching crisis proportions, are showing a sharp rise in foreign-nurse use, as are long term care (LTC) and home-care facilities across the nation (Skillman, Palazzo, Keepnews, \& Hart, 2006; Redfoot \& Houser, 2005).

As new communities seek foreign nurses, a variety of creative measures to attract and keep new recruits, such as providing low rental housing or homebuyer's assistance in areas with higher costs of living, are being implemented (Freeman, 2006; "Housing deal attracts nurses from abroad," 2006). These efforts are supported by U.S. immigration policies as well as some states' efforts to ease foreign nurse access, such as eliminating the Commission on Graduates of Foreign Nursing Schools (CGFNS) qualifying examination (Brush \& Sochalski, 2007). The qualifying examination constitutes one of three parts of the CGFNS certification process. The other two parts consist of verifying nurses' credentials (necessary as part of the VisaScreen program mandated by the Illegal Immigration Reform and Immigrant Responsibility Act of 1996) and certifying nurses' English-language proficiency. The CGFNS qualifying exam was required for internationally-trained nurses to take the U.S. National Council Nurse Licensing Examination (NCLEX); eliminating this requirement allows nurses to take the NCLEX without an additional preliminary examination of nursing knowledge. As a measure to help speed up the process of immigration, not surprisingly, organizations in 5 of the 11 states that waive the CGFNS qualifying examination also employ the greatest number of foreign nurses. California, Florida, Maryland, Massachusetts, Michigan, New Jersey, New Mexico, New York, Ohio, Texas, and Utah waive the qualifying examination.

\section{New Markets, New Competition}

The Philippines has been the top supplier of nurses to the US and the world for over a half a century (Choy, 2004). The country's dominance as the world's leading nurse exporter, however, is giving way to other countries increasingly preparing their nurses for the international marketplace (Brush \& Sochalski, 2007). In 2004, for example, India surpassed the Philippines in number of nurses admitted to the U.K.'s Nurse Register for the first time, while, in the US, Indian, Chinese, Arab, Nigerian, and Kenyan nurses inched up in numbers vying for CGFNS certification over the past decade (Table 1; CGFNS, 2006; Nurse \& Midwifery Council, 2005). South Korean nurses led all foreign nurse applicants seeking credential verification in New York State between 2004-2006 (CGFNS, 2005), and Chinese nurses, discussed as "possible" nurse migrants four years ago (Xu, 2003), are now migrating abroad in such large numbers that in early 2006, concerns were voiced about the nursing brain drain on Taiwan's public health, particularly as it related to care of the elderly (Hsu, 2006).

The shift in countries from which nurses are emigrating also reflects a departure from nurse recruitment that was previously focused primarily on countries with colonial linkages, i.e. the US and the Philippines and the UK and South Africa and Australia. Another change is that traditional suppliers of nurse emigrants are now experiencing their own nurse shortages (Chaguturu \& Vallabhaneni, 2005). While these linkages remain intact, officials in recruiting countries who relied on familiar labor pipelines are looking elsewhere and those in "donor nations" are recruiting (Nelson, 2004; Thomas, 2006). Although improving salaries remains

\begin{tabular}{|c|c|c|}
\hline 1990-1995 & 1996-2000 & 2000-2006 \\
\hline 1. Philippines (52189) & 1. Philippines (27178) & 1. Philippines (51838) \\
\hline 2. Nigeria (1777) & 2. India (1981) & 2. India (24242) \\
\hline $\begin{array}{l}\text { 3. United Kingdom } \\
\text { (1675) }\end{array}$ & 3. Canada (1840) & 3. Nigeria (2425) \\
\hline 4. Saudi Arabia (1319) & 4. Nigeria (1742) & 4. China (1020) \\
\hline 5. India (900) & 5. United Kingdom (478) & 5. UAE ${ }^{\mathrm{a}}(752)$ \\
\hline 6. UAE (809) ${ }^{\mathrm{a}}$ & 6. Japan (268) & 6. Kenya (588) \\
\hline 7. Korea (681) & 7. Poland (253) & 7. Saudi Arabia (562) \\
\hline 8. Canada (581) & 8. China (244) & 8. Canada (561) \\
\hline 9. Ireland (550) & 9. Ghana (222) & 9. Kuwait (559) \\
\hline 10. Hong Kong (458) & 10. USSR (196) & 10. Taiwan (545) \\
\hline
\end{tabular}

Note. Information was created from Commission on Graduates of Foreign Nursing Schools data collated in 5-year periods. ${ }^{\mathrm{a}} \mathrm{UAE}=$ United Arab Emirates. 
the driving force for migration, nurses report other motivations for accepting overseas positions such as unsafe work conditions and limited career prospects at home (Awases, Nyoni, Gbary, \& Chatora, 2004; International Organization for Migration, 2004; Larsen, Allan, Bryan, \& Smith, 2005).

Officials in donor and recipient nations often collaborate in their efforts to procure nurses for export and ensure workplace readiness. Korean nurses, noted in recent years to experience difficulty with language and the stress of cultural transition to the US (Yi \& Jezewski, 2000) are now being recruited by the thousands, with special measures in place to facilitate language competency and job adjustment (Carpenter, 2006). For example, a 5-year plan is currently underway between St. John's Riverside Hospital in New York and two South Korean agencies to hire as many as 10,000 South Korean nurses to New York City, with the first contract at St. John's, whose own Cochran School of Nursing supplies nurses to over 100 city hospitals (Benson, 2006; Grossman, 2006; Rozycki, 2006). Nurses recruited to St. John's undergo an 18-month internship during which they earn $\$ 25$ per hour $(\$ 52,000$ per annum) and receive intensive English language instruction. The agreement, signed in April 2006 and initiated in summer 2006, began with 50 to 100 South Korean nurses who successfully passed the NCLEX and completed the language program (Carpenter, 2006).

Over the past 5 years, India has also had significantly increased nurse exportations (Evans, 2006). Nurses from India registered to work in the UK, for example, increased from 30 in 2000 to 3,690 in 2004-2005 (Nurse \& Midwifery Council, 2005), while in the US, Indian nurses taking the CGFNS exam increased 12-fold between 1996 and 2006 (from 1,981 to 24,242).

Underlying the surge in Indian nurse emigration is the creation of new businesses focusing on global nurse staffing. The largest, the Apollo Institute of Health Sciences, represents a network of Indian hospitals that developed a forprofit Global Nurse Program to prepare nurses specifically for export to the US, UK, and Australia. Its three nursing colleges admit 130 bachelor's degree and 5 master's students annually and its five hospital schools of nursing prepare another 270 diploma graduates yearly. Plans are underway to double its nurse training programs, develop a second master's program, and initiate a doctoral program by 2007 to produce more widely-prepared nurses for export (Evans, 2006). Max India and its 3-year international nursing program is also preparing nurses for the global market while World Health Resources and Athma Healthcare have partnered with Arizona-based United Staff Solutions to bring Indian nurses to its hospitals. Developers of the latter program, set to begin in summer 2007, mandate that its nurses participate in a 30-day orientation to American culture along with speech therapy to decrease non-English accents (Evans, 2006; Gately, 2006).

Efforts to increase language competency, ameliorate accents, and facilitate nurses' adaptation to their new cul- tural surroundings are gaining popularity in the US and elsewhere (Dubois, Padovano, \& Stew, 2006; Gerrish \& Griffith, 2004). Companies that specialize in preparing information technology and call-center workers in voice modulation and cultural grooming are now partnered with hospital groups and nurse recruitment agencies and reinforce the market's shifting expectation of nurse migrants from temporary workers to long-term employees who must be "fit for duty, communicate in English, and be accent free"(Brush $\&$ Vasupuram, 2006, p. 182).

\section{Consequences of Change: The Philippines Example}

Because of its position as the world's largest nurse exporter, the situation in the Philippines is an important example of how current trends in international nurses' mobility may affect local balances of health workforce and public health needs. For example, to maintain its prominence in the shifting global nurse marketplace, the Philippines has implemented new strategies to ease nurse exportation and ensure employment of its migrating nurses. This year, the Philippines will finally have an NCLEX test site in Manila that will make preparing for practice in the US easier for nurses (Bondoc, 2007). Efforts to manage migration to neighboring countries have also been instituted. The Japanese-Philippines Economic Partnership Agreement (JPEPA), passed on September 9, 2006, promotes the flow of goods, services, and capital between Japan and the Philippines; trading human resources is a key element of the agreement, with 1,000 Filipino nurses and other health workers expected to enter Japan over the next 2 years ("The JapanPhilippines economic partnership agreement," 2006; "Our nurses in Japan,” 2007).

Meanwhile, the Filipino population faces its own dilemma in health workforce preparation and management. Nursing schools, inundated with applicants, are experiencing low national pass rates, largely because student numbers are outpacing available faculty supply and high quality programs (Brush \& Sochalski, 2007). Even with discriminate admission and attempts by the Commission on Higher Education to ensure that Philippines' nursing schools meet minimum quality standards of education, only 12 of the country's 175 nursing schools had pass rates of $90 \%$ or higher in 2004-2005 ("The best and top performing nursing schools," 2006).

Pressure to succeed might have been the impetus behind a cheating scandal in June 2006, when nurse test takers were accused of procuring advanced copies of answer sheets on the Philippines nurse licensure examination. Despite these allegations, only $42 \%(17,871)$ of 42,006 candidates passed the examination, down from $51.5 \%$ the previous year (Galford \& Rosario, 2006; "Nurse licensure examination results," 2005). Unable to discern cheaters from noncheaters, CGFNS denied VisaScreen certificates to passing test takers 9 months later and mandated that they retake two parts of the licensure examination known to have been compromised (Nichols, 2007). 


\section{Steps To Balance Global Nurse Imbalance}

As the international trade in nurses grows virtually unabated, international organizations have designed initiatives and created policies to address nurse workforce development and retention. In 2001, for example, the International Council of Nurses published its position statement governing nurse mobility and the ethical recruitment of nurses internationally (ICN, 2001). Last year, WHO (2006) issued "Working Together for Health," calling for strategies to improve nurse education and employment to promote retention and decrease national nurse shortages. Officials in the Organization for Security and Cooperation in Europe and International Organization for Migration (2006) are urging leaders in various countries to practice managed migration to meet the needs and preserve the rights of key players involved in the global nurse market, while other stakeholders, such as the Joint Learning Initiative (2004) and Physicians for Human Rights (2004) support labor migration policies that maintain healthy systems of care for local populations.

These efforts, aimed largely at national policy makers and directors of systems of care delivery and provider education, are hardly new. Twenty years ago, at the 1986 Acapulco Conference of the Council for International Organizations of Medical Sciences (CIOMS), WHO Director, Dr. Mahler, noted that adequate health professions planning, production, and management were dependent on collaboration among educators, employers, policy makers, and society and that, without such collaboration, national healthfor-all strategies would be implausible (Bankowski \& Fülöp, 1987). Today, many of the global health manpower problems discussed in Acapulco continue unabated or have escalated in magnitude: maldistribution (especially between rural and urban communities); inequalities in healthcare access and provider-to-patient ratios; and inadequate resource allocation for training and remuneration.

The Philippines is not the only "donor nation" struggling to manage its own nurse workforce in the presence of global nurse demand. Last year, the Nurses Association of Jamaica (NAJ), long aware of its nurses migrating abroad, demanded that the Jamaica government raise salaries as incentive for nurses to stay. Coordinating national demonstrations to emphasize the gravity of low staffing and poor wages, nurses threatened strikes if the government failed to respond ("Protesting nurses," 2006). Nurses in Zambia staged strikes over the past 2 decades to protest chronic understaffing, dangerous nurse to patient ratios, poor salaries, and many other issues; in summer 2006, still far from realizing changes in remuneration, work environments, or professional growth and development, Zambian nurses went on strike again ("Go back to work," 2006). The alternative for many nurses, however, is to "head for greener pastures."

Leaders in "recruiting countries" too are facing internal pressures while attempting to balance nurse demand with an international supply of nurses. Beginning in August 2006, for example, officials in the UK limited nurse recruitment to European Union (EU) countries and only granted work permits to nurses from non-EU countries if National Health
Services institutions showed that jobs could not be filled by UK or EU applicants (Depasupil, 2006). The American Nurses Association has been vocal about escalating nurse migration and its opposition to US immigration policies that lift visa caps for importing nurses. The organization is calling for "homegrown solutions" rather than reliance on foreign nurses to fill nursing staff vacancies (Doheny, 2006, p. 39). Likewise, Japanese nurses are questioning their own job security with the new Japanese-Philippines Economic Partnership Agreement now in place; some nurses are even vowing to block the entry of Filipino nurses altogether ("Obstacles to entry of RP nurses," 2006).

\section{Conclusions}

Despite ongoing debate about how best to manage nurses' international mobility, nurse migration remains relatively unchecked, uncoordinated, and individualized, such that some countries suffer from its effects while others benefit. This is not surprising given the varied nature of nurse migration between countries, inconsistent approaches to nurse migration management, and the proliferation of independent recruitment agencies.

Some have argued that strategies to manage nurse migration can only achieve success if all stakeholders are involved (Schmid, 2004). Others contend that policies remain largely directed at the symptoms of the problem rather than the context that creates workforce inequity (Brush \& Sochalski, 2007). To be effective, nurse migration policy and guidelines for ethical recruitment must consider the specific needs and motivations of various stakeholders as well as ways to regulate more carefully the private business interests of recruiters and others actively recruiting nurses.

Global policies to manage nurse migration fail because neither developed nor developing countries are creating sustainable professional nurse workforces that meet their own needs. Bilateral agreements between some countries and efforts by others to manage international nurse recruitment are a good beginning but fail to address fundamental deficiencies in the systems that created the need for such strategies in the first place. Whether losing nurses through migration or attrition, countries lower their capacity to provide adequate quality health care to their constituents when they under-invest in nursing. National policy makers must first consider how to maximize human resources to build nursing capacity without looking outward for solutions. This includes improving nurses' work conditions, educational capacity, salaries, professional growth and development, and broader roles in public health policy and practice. When nurses choose to migrate, they should be uniformly regulated through governments rather than through independent agencies so that their paths to employment are fair, visible, and measurable. Unless these efforts are coordinated among nations and consideration is given to those who will implement, regulate, and measure their effectiveness, they are unlikely to succeed. 


\section{Clinical Resources}

Migration of health professionals in six countries: A synthesis report. http://www.ilo.org/public/english/dialogue/sector/papers/health/wp209.pdf

International migration of health workers: Labour and social issues. http://www.ilo.org/public/english/ dialogue/sector/papers/health/wp209.pdf

Migration of nurses: Trends and policy implications. http://www.hrhresourcecenter.org/node/597

International Council of Nurses

http://www.icn.ch/global/

International migration, remittances, and the brain drain http://econ.worldbank.org/.../main?theSitePK= 1572893\&contentMDK=20693491\&pagePK=64168182 \&piPK=64168060

Regional Network for Equity in South Africa (EQUINET)

www.queensu.ca/samp/migrationresources/braindrain/ documents/equinet.pdf

The role of wages in the migration of health care professionals from developing countries http://www.human-resources-health.com/content/2/1/3

\section{References}

Awases, M., Nyoni, J., Gbary, A. \& Chatora, R. (2004). Migration of health professionals in six countries: A synthesis report. Geneva, Switzerland: World Health Organization, WHO Regional Office for Africa, Division of Health Systems and Services Development.

Bankowski, Z., \& Fülöp, T. (1987). Health manpower out of balance: Conflicts and prospects: Highlights of the Acapulco conference. XXth Council for International Organizations of Medical Sciences Conference, Acapulco, Mexico, 7-12 September 1986.

Benson, B. (2006). NY to fill nurse shortage with recruits from Korea. Crain's New York Business, 22(23), 27.

The best and top performing nursing schools in the Philippines. Retrieved February 13, 2007, from http://www.pinoysites. org/jcm/item/5/

Bondoc, J. (2007, February 12). Gotcha, ABS-CBN interactive. Retrieved February 13, 2007, from http://www.abscbnnews.com/storypage. aspx? StoryId+66459

Brewer, C.S., Feeley, T.H., \& Servoss, T.J. (2003). A statewide and regional analysis of New York State nurses using the 2000 national sample survey of registered nurses. Nursing Outlook, 51(5), 220-226.

Brush, B.L., \& Berger, A.M. (2002). Sending for nurses: Foreign nurse migration, 1965-2002. Nursing and Health Policy Review, 1(2), 103115.

Brush, B.L., \& Sochalski, J. (2007). International nurse migration: Lessons from the Philippines. Policy, Politics, and Nursing Practice, 8(1), 37-46.

Brush, B.L., Sochalski, J., \& Berger, A. (2004). Imported care: Recruiting foreign nurses to US health care facilities. Health Affairs, 23(3), 78-87.

Brush, B.L., \& Vasupuram, R. (2006). Nurses, nannies and caring work: Importation, visibility, and marketability. Nursing Inquiry, 13(3), 181185.

California Board of Registered Nursing. (2004). Survey of registered nurses in California 2004. Retrieved December 15, 2006, from http://www.rn.ca.gov

Carpenter, C. (2006). US to recruit 10,000 Korean nurses. The Korean Times. Retrieved June 27, 2006, from http://times.hankook.com/ lpage/nation/200604/kt2006041418220911980.htm
Center for California Health Workforce Studies. (2005). Forecasts of the registered nurse workforce in California. Retrieved December 15, 2006, from http://www.in.ca.gov/forms/pdf/forecasts2005.pdf

Chaguturu, S., \& Vallabhaneni, S. (2005). Aiding and abetting-nursing crises at home and abroad. New England Journal of Medicine, 353(17), 1761-1763.

Choy, C.C. (2004). Empire of care: Nursing and migration in Filipino American history. Durham, NC: Duke University Press.

Commission on Graduates of Foreign Nursing Schools. (2005). Credentialing verification service for New York state data 2005. Retrieved July 12, 2006, from http://www.cgfns.org/sections/research/ data/cvs/cvs_data.shtml

Commission on Graduates of Foreign Nursing Schools. (2006). Certification program data. Retrieved July 12, 2006, from http://www.cgfns. $\mathrm{org} /$ sections/research/data/cp/cp_data.shtml

Depasupil, W.B. (2006, August 9). No hiring ban of RP nurses in UK. The Manila Times. Retrieved March 13, 2007, from http://www. manilatimes.net/national/2006/aug/09/yehey/metro/20060809met4.html

Dubois, H.F.W., Padovano, G., \& Stew, G. (2006). Improving international nurse training: An American-Italian case study. International Nursing Review, 53(2), 110-116.

Doheny, K. (2006). Treating the nurse shortage. Workforce Management, 85(19), 39-40, 42. Retrieved November 9, 2006, from www.workforce.com

Evans, M. (2006). Help from India, Inc. Modern Healthcare, 36(2), 28-30.

Freeman, L. (2006, December 17). Hospitals get creative with recruitment. Naples Daily News. Retrieved December 18, 2006, from http://www. naplesnews.com/news/2006/dec/17/get_creative_recruitment/ ?housing

Galford, J.C., \& Rosario, B.R. (2006, July 29). Senate, house seek inquiry on nursing board exam. The Manila Bulletin Online. Retrieved July 29, 2006, from http://www.mb.com.ph/MTNN2006072970364.html

Gately, E. (2006). E.V. nurse staffing agency OKs international deal. East Valley Tribune.com. Retrieved July 29, 2006, from http://www. eastvalleytribune.com/index.php? sty $=70535$

Gerrish, K., \& Griffith, V. (2004). Integration of overseas registered nurses: Evaluation of an adaptation programme. Journal of Advanced Nursing, $45,579-587$.

Go back to work. (2006, August 22). The Post. Retrieved August 23, 2006, from http://allafrica.com/stories/printable/200608220749.html

Grossman, J. (2006, May 7). Labor: New reinforcements for the nursing ranks. The New York Times. Retrieved October 12, 2007, from http:// query.nytimes.com/gst/fullpage.html?res=940EED91E3FF934A35756 COA9609C8B63

Health Resources and Services Administration. (2006). Preliminary findings: 2004 national sample survey of registered nurses. Retrieved July 13, 2006, from http://bhpr.hrsa.gov/healthworkforce/reports/ rnpopulation/preliminaryfindings.htm

Housing deal attracts nurses from abroad. (2006, July 19). Newsday.com. Retrieved July 20, 2006, from http://www.newsday.com/news/local/ longisland/nylinurs0719,0,5838664.story?coll=ny-to

Hsu, J. (2006, March 4). Nurses groups warn of mass exodus to US. Taiwan News. Retrieved March 10, 2006, from http://www.etaiwannews. com/etn/index_en.php

International Council of Nurses. (2001). Position statement on ethical nurse recruitment. Retrieved August 18, 2006, from http://www. icn.ch/psrecruit01.htm

International Organization for Migration. (2004). The development dimension of migrant remittances. Geneva, Switzerland: Author.

The Japan-Philippines economic partnership agreement. (2006). Retrieved February 13,2007, from http://www.philexport.ph/JPEPA\% 20BRIEFER\%20final.doc

Joint Learning Initiative. (2004). Human resources for health: Overcoming the crisis. Retrieved June 1, 2006, from http://www.globalhealthtrust. org/report/Human_Resources_for_Health.pdf

Kingma, M. (2006). Nurses on the move: Migration and the global health care economy. Ithaca, NY: Cornell University Press.

Larsen, J.A., Allan, H.T., Bryan, K., \& Smith, P. (2005). Overseas nurses' motivations for working in the UK: Globalization and life politics. Work, Employment, and Society, 19(2), 349-368.

Nelson, R. (2004). The nurse poachers. The Lancet, 364, 1743-1744. 
New York State Education Department. (2003). Results of the September 2002 survey of registered professional nurses, Vol. I. Retrieved August 3, 2006, from http://www.op.nysed.gov/nursing-survey-finalregents-report.htm\#demo

Nichols, B. (2007, February 21). Further information on February 14 announcement: CGFNS denies VisaScreen certificates for Philippine nurses who passed the compromised June 2006 Philippine licensure examination. CGFNS International News Release. Retrieved February 21, 2007, from www.cgfns.org

Nurse licensure examination results. (2005). Manila Standard Today Online. Retrieved March 13, 2007, from http://www.manilastandardtoday. com/?page=nurse_dec_19_2005

Nurse \& Midwifery Council. (2005). Statistical analysis of the register, 1 April 2004to 31 March, 2005. Retrieved March 6, 2007, from http://www.nmc.uk.org/aFrameDisplay.aspx?DocumentID= 856

Organization for Security and Cooperation in Europe and the International Organization for Migration. (2006). Handbook on establishing effective labour migration policies in countries of origin and destination. Retrieved August 16, 2006, from http://www.osce.org/ publications/eea/2006/05/19187_620_en.pdf

Our nurses in Japan. (2007). The Manila Times. Retrieved February 13, 2007, from http://www.manilatimes.net/national/2007/jan/09/ yehey/opinion/20070109opi1.html

Physicians for Human Rights. (2004). An action plan to prevent brain drain: Building equitable health systems in Africa. Boston, MA: Physicians for Human Rights.

Polsky, D., Ross, S.J., Brush, B.L., \& Sochalski, J. (2007). Trends in characteristics and country of origin among foreign-trained nurses in the United States, 1990 and 2000. American Journal of Public Health, 97(5), 895899.

Protesting nurses not ruling out shutdown of hospitals. (2006).

The Jamaica Observer Internet Edition. Retrieved July 16, 2006, from http://www.jamaicaobserver.com/news/html/20060711T0100000500_108842_OBS_PRO
Redfoot, D.L, \& Houser, A.N. (2005). 'We shall travel on': Quality of care, economic development, and the international migration of longterm care workers. Washington, DC: AARP Public Policy Institute.

Reineck, C., Furino, A., Lucke, J., Martinez, J., \& Wood, R. (2005). Health and nurses in Texas: In their own words: 2004 survey of Texas registered nurses (Vol. 2, No. 3). Retrieved January 4, 2007, from http://www. uthscsa.edu/RCHWS/Reports/2004RN\%20Survey\%20\%20Texas. $>$ pdf

Rozycki, B. (2006, April 24). S. Korea, St. John's sign nurse pact. Westchester County Business Journal, 45(17), 1.

Sanchez, E.J., \& Raimer, B.G. (2004). Migration trends: Texas RNs and LVN workforce. January 4, 2007, from http://www.dshs.state.tx.us/ chs/migration.pdf

Schmid, K. (2004). Strategies to manage migration of health professionals to protect national health systems will be successful only if all stake holders are involved in the process. Bulletin of the World Health Organization, 82(8), 621-22.

Senate of the Philippines. (2006). Obstacles to entry of RP nurses to Japan exist despite JDEPA. Retrieved March 13, 2007, from http://www.senate.gov.ph/press_release/2006/1201_pimentel1.asp

Skillman, S.M., Palazzo, L., Keepnews, D., \& Hart, L.G. (2006). Characteristics of registered nurses in rural versus urban areas: Implications for strategies to alleviate nursing shortages in the United States. National Rural Health Association, 22(2), 151-157.

Texas Center for Nursing Workforce Studies. (2006). Texas hospital nurse staffing: 2006. Retrieved January 4, 2007, from http://www. dshs.state.tx.us/chs/cnws/2006HNSS.pdf

Thomas, P. (2006). The international migration of Indian nurses. International Nursing Review, 53, 277-283.

World Health Organization. (2006). Working together for health. Geneva, Switzerland: Author.

Xu, Y. (2003). Are Chinese nurses a viable source to relieve the U.S. nurse shortage? Nursing Economics, 21(6), 269-279.

Yi, M., \& Jezewski, M.A. (2000). Korean nurses' adjustment to hospitals in the United States of America. Journal of Advanced Nursing, 32(3), 721-729. 